\title{
Violent Media, Guns, and Mental Illness: The Three Ring Circus of Causal Factors for School Massacres, as Related in Media Discourse
}

\author{
Jaclyn Schildkraut, Glenn W. Muschert
}

"When something like this happens, everybody says it's an epidemic, and that's just not true" (Amanda Nickerson, in Glaberson, 2012). While this reaction to the December 14, 2012 shooting at Sandy Hook Elementary School[1] is one of the more realistic responses to the event, it also is rather uncharacteristic. When news of a school shooting breaks, most people struggle to come to terms with the tragedy and begin their quest for answers to a number of questions. One of the most elusive answers is to the question of "why" the event has happened (Schildkraut, 2012a).

In an effort to answer this question, two groups have emerged as key narrators of the school shootings story. First, the mass media are responsible for breaking the news and providing audiences with information on the shooters, the victims, and the events. Once the audience receives this information, they then turn to the second group - politicians - to report on the response and "official reaction." In addition to seeking answers to why these events happen, members of society also rely on their elected representatives and political figures to help put the event in perspective, and to look for ways to prevent the next tragedy. Both of these key narrators are filtered through mass media, as journalists themselves frame and comment upon the tragedies, and as politicians reach their constituents and broader audiences via media reportage.

New Hampshire Senator Kelly Ayotte recently weighed in on the tragedy in Newtown, stating, "Ultimately when we look at what happened in Sandy Hook we should have a fuller discussion to make sure that it doesn't happen again" (Kelly Ayotte, quoted in Associated Press, 2013). While a similar sentiment has been echoed following other mass shootings in schools, both the media and politicians continue to focus on three major themes - guns, mental health, and violent media. This discourse may be supplemented by considerations of individual and sociological causes, including the roles of family, religion, and community. These latter topics, however, play a supporting role to the stories' main cast of issues around which to frame school massacres.

While these stories are presented to the public in a neat, succinct news package or article, the reality is that it's not quite so simple. Rarely can events so unpredictable and difficult to explain be reduced to a simple narrative; yet this doesn't stop the media and politicians from trying. This chapter explores the discursive construction of school shootings stories, from how the media covers these events to the themes interwoven through the political rhetoric. Specifically, we examine three prominent school shootings - 2012's Sandy Hook as well as it's equally infamous predecessors Columbine (1999)[2] and Virginia Tech (2007)[3] - and how relatively short-lived, random events have turned into unprecedented "media spectacles" (Kellner, 2003, 2008a, 2008b) and moral panics (Burns \& Crawford, 1999; Schildkraut, Elsass, \& Stafford, 2013; Springhall, 1999).

\section{| We Interrupt This Program with Breaking News of a Shooting...}

When news of a school shooting breaks, the media rush to the scene to begin a barrage of coverage that can 
last days and even weeks. News stations, particularly 24-hour news networks such as CNN, Fox News, and MSNBC, cover every facet of these stories throughout their wall-to-wall coverage (Elsass \& Schildkraut, 2013). Newspapers capture audiences with sensationalized headlines and are able to generate more stories between printings through their digital counterparts (Elsass \& Schildkraut, 2013). The end result is that these relatively uncommon events are highly sensationalized, thereby making them appear considerably more common than they are (Kellner, 2008a; Surette, 1992).

Following Newtown, journalist David Carr (2013) wrote that "[our] job as journalists is to draw attention, to point at things, and what we choose to highlight is defined as news." As most people will never experience a school shooting, the media become their only outlet to these phenomena (Jewkes, 2004; Mayr \& Machin, 2012; Robinson, 2011). Researchers have shown that for up to $95 \%$ of the general public, any information they receive, particularly about crime, comes via the media (Graber, 1980; Surette, 1992). It then appears that the media must operate under the motto, as Uncle Ben told Peter Parker in Spiderman, "with great power comes great responsibility" (Ziskin, Bryce, \& Raimi, 2002). Yet does this happen?

In a 2013 article, New York Times opinion columnist Ross Douthat tackled this quandary. In his analysis of partisanship in the media, Douthat (2013) suggests that the mainstream media act "as a crusading vanguard while denying, often self-righteously, that anything of the sort is happening." Though this statement was made in the context of the nation's fiscal crisis, he goes on to link it to the recent Newtown shootings:

The trouble is that when you set out to 'lead' a conversation, you often end up deciding where it goes, which side wins the arguments and even who gets to participate. (Douthat, 2013)

This trouble is often the result of the discord between journalistic neutrality and editorial choices (Douthat, 2013). He discusses two particular editorial choices that are especially relevant to the public's understanding of school shootings.

First, Douthat (2013) notes some stories receive continuous, or "wall-to-wall," coverage, while others are buried. Columbine, for instance, became the biggest news story of its year, as well being one of the most followed stories of the entire decade (Pew Research Center for the People \& the Press, 1999; Robinson, 2011). Similarly, Virginia Tech was also the biggest story of a news week that included coverage of the war in Iraq, a Supreme Court ruling on abortion, and the upcoming presidential election (Pew Research Center for the People \& the Press, 2007). Sandy Hook was the second most followed story of 2012, falling just short to that year's presidential election (Pew Research Center for the People \& the Press, 2012). The end result is that the media focus on several high profile cases, which can give viewers a misinformed understanding of the frequency of occurrence (Burns \& Crawford, 1999; Kellner, 2008a; Muschert, 2007a; Muschert \& Ragnedda, 2010; Newman, 2006). In reality, school shootings occur at an average of less than 10 events per year (Schildkraut, 2012a).

Beyond where the story ranks in terms of perceived importance, the sheer volume of coverage these events receive also greatly influences public understanding of these events as the continuous coverage makes these events all but inescapable. For the first month following Columbine, for example, three of the major networks - ABC, CBS, and NBC - devoted a minimum of half their evening news coverage to the shooting, totaling 319 stories (Robinson, 2011). Another study (Maguire, Weatherby, \& Mathers, 2002) found similar results when examining the first week of coverage of Columbine compared to 13 other shootings. The same three major networks aired 53 stories and four hours of coverage on Columbine, while the remaining shootings combined totaled nearly the same amount of coverage (Maguire et al., 2002). Following the Virginia Tech shooting, particularly after NBC News released Cho's multimedia manifesto, the backlash from the volume of coverage was so pervasive that NBC executives limited their coverage of the event to $10 \%$ of total airtime (Schildkraut, 2012b). Prior to this, however, CNN and Fox News had registered 1.4 million and 1.8 million viewers respectively on the day of the shooting (Garofoli, 2007). By comparison, these networks typically averaged 450,000 (CNN) and 900,000 (Fox News) daily viewers in the year prior to the shootings (Pew Research Center's Project for Excellence in Journalism, 2006).

Following Columbine, over 10,000 stories about the shooting appeared in the nation's top 50 newspapers (Newman, 2006), including 170 articles published in the New York Times alone (Chyi \& McCombs, 2004; Muschert \& Carr, 2006). Over 130 articles were published between the Times and the New York Post following Virginia Tech (Schildkraut, 2012a). Coverage of Sandy Hook in the New York Times in the month following the shooting also reached over 130 articles excluding op-eds and blogs (Schildkraut \& Muschert, 2013). Increases in media coverage also can be observed through online coverage statistics. Following Virginia Tech, for instance, MSNBC. 
com registered 108.8 million page views (Garofoli, 2007). On an average day, the site registers around 400,000 page views (TheWebStats.com). What is perhaps most staggering about these numbers is that other shootings, such as the 1999 Conyers, GA shooting (one month after Columbine), the 2008 Northern Illinois University shooting, or the 2012 Chardon, Ohio high school shooting, have failed to garner equitable media attention. This confirms Kellner's (2003, 2008a, 2008b) "media spectacle" related to Columbine, Virginia Tech, and Sandy Hook, each of which have become iconic and archetypal of school shootings in their own right.

Douthat (2013) also notes that a conscious decision is made to cast one side as aggressors and the other as the aggrieved.4 This is perhaps easier to discern when examining mass murder in schools - there is a clear aggressor (the shooter) and aggrieved (the victims). With the media, however, the conscious decision is less about who is cast in which role and more about which actor gets the most coverage and airtime. While a considerable amount of coverage of the Columbine victims appeared across major news outlets, such as the New York Times, Associated Press, ABC News, CNN, and PBS News (Muschert, 2007b), the majority of the coverage centered on the shooters, Eric Harris and Dylan Klebold (Muschert, 2007b; Schildkraut \& Muschert, 2013). One of the most iconic images to be published of the shooting was a still frame of the shooters in the school's cafeteria, which made the December 1999 cover of Time magazine (Schildkraut \& Muschert, 2013).

A similar disparity in coverage between the aggressor and the aggrieved also was noted in the case of Virginia Tech. In 113 articles examined from the New York Times and the New York Post, there were a total of 413 references (177 and 236, respectively) to the shooter, Seung-Hui Cho (Schildkraut, 2012a). By comparison, there were less than 100 references combined between the two papers for all 32 victims (Schildkraut, 2012a). Further, in both Muschert's (2007b) and Schildkraut's (2012a) examinations of the coverage of these events, it was observed that the media created further disparity with their reporting of selective individuals. In each case, only a handful of victims received an increased amount of attention, whereas most victims received only one or two mentions, if they were covered at all (Muschert, 2007b; Schildkraut, 2012a).

While the coverage of the Sandy Hook shooting also clearly defined the aggressor (shooter Adam Lanza) and the aggrieved (the 20 first grade students and six of their educators), this coverage visibly departed from the framework laid out by the earlier events (Schildkraut \& Muschert, 2013). Specifically, a considerably larger amount of coverage focused on reporting on the victims rather than the shooter (Schildkraut \& Muschert, 2013). While additional research is needed to understand the full impact in this new reporting trend, Sandy Hook marked one of the first shifts from "offender-centered reporting" to "victim-centered reporting" (Schildkraut \& Muschert, 2013, p. 22), a developing discourse that dovetails with effects to identify who (or what) is responsible for such attacks.

\section{Who Is To Blame?}

Perhaps one of the more interesting discourses that have emerged following each of these school shootings is the idea that the cause of the event must be bigger than the shooters themselves. It is not acceptable just to say that one or two angry young men went into a school and committed homicide. Instead, there has to be some greater reason that these events have occurred in order to make what has happened understandable, or possibly even manageable. While the media fuel this speculation, they often do so by serving as a vehicle for politicians, pundits, and the public to weigh in. The sources of these events have manifested themselves into two different camps proponents of individual causes and proponents of social causes.

\section{Individual Responsibility}

It is possible that, although the answer cannot be as simple as "they were angry," the shooters themselves can be held responsible for their actions. What is perhaps more noticeable in this discourse, however, is that this accountability is more the result of some sort of individual defect that has turned these young males into killers. These arguments tend to deny the influence of the social world, and place the blame solely on the offenders. By doing so, it becomes unnecessary to acknowledge any shortcomings in the sociological structure, and less necessary to demand that there is change in such a realm.

One such sentiment suggests individual affect or personality defects as causative. For example, Dan Quayle in the wake of Columbine, commented that "The overriding issue isn't really gun control - it's self-control" (in Seelye, 1999). Vikki Buckley, the Colorado Secretary of State at the time Columbine occurred, was quoted as saying 
"Guns are not the issue. Hate, what pulled the trigger of violence, is the issue" (in Seelye \& Brooke, 1999). Similar sentiments followed Newtown: "A gun didn't kill all those children, a disturbed man killed all those children" (Scott Ostrosky, in Moss \& Rivera, 2012).

In other instances, it is not so much the presence of a negative characteristic as much as it is the absence of ones considered to be positive. One of the main points of argument in this instance is religion. This discourse was the most prominent following Columbine, particularly as the area is extremely religious and amidst rumors that two of the victim, Rachel Scott and Cassie Bernall, were killed for affirming their beliefs in God to the shooters (Muschert, 2007b). Dan Quayle opined "A child who loves God, honors his parents and respects his neighbors will not kill anyone" (in Seelye, 1999). In an interview on Larry King Live following the event, then-Vice President Al Gore elaborated, saying:

We have with our power of conscience, with our beliefs in God, if we have those, as most of us Americans do, we have the ability to - to overcome those impulses with higher ones. We have the ability to overcome evil with good. (in Walker, 1999)

Interestingly, following the Virginia Tech shootings, discussion of religion was notably absent, with the exception of a single line in an editorial:

Over the next few days, we'll ponder the sources of Cho Seung-Hui's rage. There'll be no shortage of analysts picking apart his hatreds, his feelings of oppression and his dark war against the rich, Christianity and the world at large. (Brooks, 2007)

This statement, though not directly implicating religion (or a lack thereof) in the shooting, is indicative of how people dissect these events and their perpetrators looking for answers.

Following the Sandy Hook shooting, the minimal amount of discourse centered on how religion benefits those who are healing:

It is a failure of community, and that's where the answer for the future has to lie. What religion has to offer to people at moments like this -- more than theology, more than divine presence - is community. (Greg Epstein [Harvard's humanist chaplain], in Freedman, 2012)

What is particularly interesting about the Sandy Hook case is that, unlike Littleton which was heavily skewed towards Christian evangelicals (Muschert, 2007b), Newtown was more diverse in religious beliefs. More importantly, this suggests that Adam Lanza was potentially excluded from this community (which is discussed in the next section).

The shooters were not the only source of blame following these events. Perhaps one of the greatest lightning rods for criticism in the school shootings discourse has been the National Rifle Association (NRA). Formed in 1871 to promote marksmanship and shooting as a sport, the NRA has grown into "America's longest standing civil-rights organization," seeking to protect the Second Amendment right to bear arms and promote firearms education (NRA. com). What is most interesting, and easily overlooked in this ongoing feud between the two sides, is that responses to these shootings from the NRA have not been markedly different from the responses from others.

In fact, the NRA was even scheduled to hold their annual meeting and exhibition in Denver in the weeks following Columbine. Out of respect, the exhibitions were cancelled and only the annual business meeting was held (Seelye \& Brooke, 1999). In his statement presented at the meeting, NRA president Wayne LaPierre stated "We believe in absolutely gun-free, zero-tolerance, totally safe schools" (in Seelye \& Brooke, 1999). Similar statements also were made following the shooting at Virginia Tech. When asked about legislative improvements for reporting mental health issues to background check systems, LaPierre responded, "We are not an obstacle. We're strongly in support of putting those records in the system" (in Luo, 2007). Still, when the public, the media, and politicians are looking for a source at which to point their finger, the NRA has been an easy target.

\section{Collective Responsibility}

Some proffered causes for school shootings are simply too broad to target just one individual or group. Instead, the focus shifts to social causes, and ultimately, the need for social change. These discussions imply that there is something wrong with the social environment. By extension, therefore, the only way to fix the "problem" of school massacres is to restructure parts of our collective sociology. As Utah Senator Orrin Hatch mused after Columbine, "We all know this is a much more complex problem than guns" (in Bruni, 1999).

One of the most prevalent social causes blamed for these mass shootings is community. This not only refers to community in the traditional sense of neighborhoods and towns, but also to the communities within communities, 
such as schools and their subcultures. Following Columbine, the typical culture of cliques seen in high schools around the nation was immediately fingered as one potential cause for the shooting. Like many other schools, Columbine placed a heavy emphasis on its athletic programs, and rumors suggesting that Harris and Klebold had specifically sought out jocks in their rampage did not help to dispel this myth (Larkin, 2007).

The role of subcultures within schools was heavily blamed as the cause for Columbine. Harris and Klebold were named as members of the Trenchcoat Mafia, which was rumored to be a group of misfits who didn't subscribe to the traditional high school culture of proms and pep rallies, and instead opted for "Goth rock" and black duster jackets or camouflage, military-style clothing (Frymer, 2009; Larkin, 2007; Springhall, 1999). As one Massachusetts principle summarized:

\begin{abstract}
In these big high-powered suburban high schools, there's a very dominant winner culture, including the jocks, the advancedplacement kids, the student government and, depending on the school, the drama kids or the service clubs. But the winners are a smaller group than we'd like to think, and high school life is very different for those who experience it as the losers. They become part of the invisible middle and suffer in silence, alienated and without any real connection to any adult. (Carol Miller Lieber, in Lewin, 1999)
\end{abstract}

Beyond the divide within the school's walls, some have mused that suburban communities also are to blame for the shootings. Columbine and other school shootings represented a shift of violence from an inner-city problem to a threat to the safety suburban and rural communities were believed to provide (Schildkraut et al., 2013). As one writer noted:

Created as safe havens from the sociological ills of cities, suburbs now stand accused of creating their own environmental diseases: lack of character and the grounding principles of identity, lack of diversity or the tolerance it engenders, lack of attachment to shared, civic ideals. Increasingly, the newest, largest suburbs are being criticized as landscapes scorched by unthoughtful, repetitious building, where, it has been suggested, the isolations of larger lots and a car-based culture may lead to disassociation from the reality of contact with other people. (Hamilton, 1999)

Another problem associated with suburban communities is the lack of presence by the parents. In many instances, children of suburban families become latch-key kids as one or both parents commute into the nearest big city for work. Politicians campaigning on family values after Columbine, such as George W. Bush, seized the opportunity to ponder this impact: "The fundamental issue is, Are you and your wife paying attention to children on a day-by-day, moment-by-moment basis?” (in Seelye, 1999).

While the community design of Littleton was targeted as a cause for the Columbine shootings, an opposite discourse emerged following the Sandy Hook shooting. Newtown has been touted as a picturesque community, the kind of community that is ideal to raise children. With its sprawling homes (some even complete with picket fences and a dog in the yard), Newtown has even been described as "tak[ing] its child-friendly, Norman Rockwell ambience seriously" (Dwyer \& Rueb, 2012). In discourse that followed the Sandy Hook shooting, the community aspect was most prominently featured in coverage about healing and restoration, rather than as a catalyst for Lanza's rampage. As with many other facets of the story, Newtown's community aspect was portrayed as a case where they did everything right.

While high schools provide fragmented communities, and suburban communities have been credited with furthering such isolation, colleges and universities also have been labeled as ostracizing environments for school shooters. While institutions of higher education also are considered to be communities, they do not function in the traditional sense of the word. Due to their size and heterogeneity (in respects to demographics, majors, and a bevy of other factors), post-secondary schools are bound to create barriers to forming strong ties to one's "community." For Cho, this was furthered by his social disorder (selective mutism) and a disdain for mainstream student culture at Virginia Tech (Schildkraut, 2012b).

\title{
"Round Up the Usual Suspects"5
}

Beyond the specific individual and social causes that have been pinpointed in the political discourse, three specific culprits have emerged as the trifecta of causes of school shootings: violent media, mental health, and guns. These issues not only are consistent in discourses following each of these events, but also transcend the individual, 
community, and even macro-social levels of concern. What is perhaps most interesting, as Dr. Jeffrey Fagan notes, "Any one of these three risks separately does not produce a violent event. It's their convergence and interaction that produces an event" (as quoted in Stolberg, 1999). It is, as Muschert (2007a) notes, the perfect storm for school shootings. Thus, in the public discourse about school massacres, these have emerged as the go-to causes, the three ring circus of blame, so to speak.

\section{Violent Media}

A causal factor appearing in reportage of school massacres has been a focus on the shooters' reported consumption of violent media. In an editorial following Columbine, Bob Herbert (1999) summarized how our culture regards violence in the media:

Welcome to America, a land where the killing is easy.... We make it exciting. We celebrate it, romanticize it, eroticize it, and mass-market the weapons that bring murder within easy reach of one and all. It's no big deal. Just pick up that handgun and drive down to the video store for a couple of exciting flicks about killing women. And if somebody cuts your car off along the way, shoot him.... We are addicted to violence. It sustains and entertains us.

Details released as part of the Columbine investigation indicated that both boys, but particularly Eric Harris, were fans of "Goth rock," such as Rammstein, KMFDM, and most notoriously, Marilyn Manson. He was, in fact, scheduled to have a concert in Denver just after the shooting, but cancelled the tour date once he was linked to the shooting and people began boycotting the show. In an op-ed piece in Rolling Stone magazine, it was Manson (1999) who actually turned the tables on the media:

From Jesse James to Charles Manson, the media, since their inception, have turned criminals into folk heroes. They just created two new ones when they plastered those dip-shits Dylan Klebold and Eric Harris' pictures on the front of every newspaper. Don't be surprised if every kid who gets pushed around has two new idols. We applaud the creation of a bomb whose sole purpose is to destroy all of mankind, and we grow up watching our president's brains splattered all over Texas. Times have not become more violent. They have just become more televised. (Emphasis added)

Although there were few, if any, links between Cho and Lanza and their consumption of the violent media, this did not stop people from speculating that it was still a cause. Some posited that Cho drew his inspiration from the South Korean film Oldboy, which features a scene in which the main character exacts retribution on his tormentors (Hendrix, 2007; Schildkraut, 2012b). He was never linked to any violent video games. Lanza was rumored to have played World of Warcraft (Lichtblau, 2013); this, however, has yet, if ever, to be confirmed. It also is possible that this speculation is actually the by-product of the media's linking of James Holmes, the perpetrator from the Aurora, Colorado movie theater shooting just five months earlier, to the same game (Lichtblau, 2013). Still, absent concrete evidence, politicians seized the opportunity to call out the media. Following Newtown, Chris Christie, the governor of New Jersey, stated

I don't let games like Call of Duty in my house. You cannot tell me that a kid sitting in a basement for hours playing Call of Duty and killing people over and over and over again does not desensitize that child to the real-life effects of violence. (in Lichtblau, 2013)

What seems to escape this discourse is the consideration of all of the people who consume these different media and don't become school shooters. Marilyn Manson has sold over 50 million albums worldwide (Blabbermouth.net, 2010). Natural Born Killers grossed over $\$ 11$ million in its opening weekend alone (BoxOffice.com, n.d.). It has been estimated that around 10 million people played DOOM, the game of choice for Columbine shooter Eric Harris, during the first two years of its 1993 release (Doom, n.d.). More recently, Call of Duty: Black Ops 2 sold over 11 million units in its first week of release (Kain, 2012).

Still, despite the millions of consumers who flock to these products for entertainment and don't, as Agger (2007) noted about Cho, "pump three bullets per victim," these coincidences have somehow become a soapbox for why violent media need to be outlawed. David Geffen, a record executive and film producer, questioned this platform, noting:

Why not blame the libraries? They're full of violent books. If you're looking for violence, what about the evening news?

America is bombing Yugoslavia; it's on every day. It's not a movie, it's real. (in Broder, 1999) 
Perhaps Alicia Silverstone's character Cher in Clueless said it best: "Until mankind is peaceful enough not to have violence on the news, there's no point in taking it out of shows that need it for entertainment value" (Rudin et al., 1995).

\section{Mental Health}

A second factor associated with causing school shootings is the frequent discussion of mental illnesses or disorders on the part of the shooters. Reports circled that Columbine shooter Eric Harris had been taking the antidepressant Luvox at the time of the shooting, which commonly is used to treat obsessive-compulsive disorder. Despite the fact that Harris wrote caustically about his hatred of his peers at Columbine, it was not until the coverage of the Virginia Tech shooting that the mental health debate became more prominent. Inquiries into shooter SeungHui Cho revealed that he had a lengthy history of mental health issues. Aside from the selective mutism (and a later diagnosis of major depression) that had plagued him since his family emigrated from South Korea when he was eight, Cho had left a number of clues about his mental state along his path at Virginia Tech. His writings became increasingly violent, and his behavior so bizarre that one professor had him removed after other students stopped attending out of fear (Virginia Tech Review Panel [VTRP], 2007). He was extremely withdrawn, claimed to have a girlfriend named Jelly (a model), and in the rare instances he did attempt to communicate with anyone, usually a female student on campus, he did so through his alter-ego "Question Mark" by leaving random scrawling on their dorm room message boards (VTRP, 2007).

Following an incident in December 2005, in which the Virginia Tech Police Department (VTPD) were called to Cho's dorm after he randomly appeared at one student's door dressed in sunglasses and a hat, Cho threatened suicide to one of his suitemates, who then called the VTPD (VTRP, 2007). Cho was taken to the station, where he was screened for mental illness intake by a member of the local community-service board (VTRP, 2007). The screener determined that Cho was mentally ill, refused to seek treatment voluntarily, and posed an imminent danger to himself or others, and contacted a magistrate to secure a detention warrant (Bonnie, Reinhard, Hamilton, \& McGarvey, 2009; VTRP, 2007). Cho was then transferred to St. Alban's Behavioral Health Center, where he underwent several examinations by independent, licensed mental health professionals prior to a commitment hearing (Bonnie et al., 2009; VTRP, 2007). Despite that these additional psychiatrists deemed Cho "an imminent danger to himself as a result of mental illness," the special justice presiding over the commitment hearing still ordered Cho to undergo outpatient treatment as a result of overcrowding at the state's facilities (VTRP, 2007, p. 48; see also Bonnie, 2009).

At the time, the Virginia code (see $\int 37.2-819$ ) required anyone who had been admitted to a mental health facility (either voluntarily or involuntarily) or who had been detained by a legal order to be reported to the Central Criminal Records Exchange (CCRE) (Schildkraut \& Hernandez, 2013). For Cho, his stint at St. Alban's was never reported, and subsequently, when he went to purchase his firearms, he was not flagged in the background check system (Roberts, 2009). When this information surfaced, then-Governor Timothy Kaine signed an executive order requiring immediate reporting to the CCRE (Schildkraut \& Hernandez, 2013) and additional legislation to improve reporting was passed in 12 other states (Brady Campaign Press Release, 2011). The following year, President George W. Bush signed into law the NICS Improvement Amendments Act and designated nearly \$1.3 billion in federal grants to improve, update, and establish reporting systems (Schildkraut \& Hernandez, 2013).

Following the Newtown shooting, it was reported that shooter Adam Lanza had Asperger's syndrome, which is a high functioning form of autism. This concern was immediately thrust into the discourse of the event and prompted fear and worry in others with the condition. In reality, as one doctor noted, "aggression in autism spectrum disorders is almost never directed to people outside the family or immediate caregivers, is almost never planned, and almost never involves weapons" (Dr. Catherine Lord, as in Harmon, 2012). Further, research has shown that no Asperger's patients (of those studied) had ever used a weapon and only about $2 \%$ had been aggressive toward someone outside their family (Harmon, 2012). Still, as Lori Shery, president of an Asperger's advocacy group, noted:

The media's continued mention of a possible diagnosis of Asperger syndrome implies a connection between that and the heinous crime committed by the shooter. They may have just as well said, 'Adam Lanza, age 20, was reported to have had brown hair.' (in Harmon, 2012)

\section{Guns}

There is perhaps no greater or more controversial culprit in the blame game of school shootings than firearms. In the aftermath of these events, the NRA and like-minded gun proponents have suggested that more guns, and 
subsequently less restrictions on guns (such as easing campus bans prohibiting concealed weapons), would help to protect the good guys from the bad guys. Following Columbine, Charlton Heston, then president of the NRA, suggested that "If there had been even one armed guard in the school, he could have saved a lot of lives and perhaps ended the whole thing instantly" (in Verhovek, 1999). Despite that there was a school resource officer on campus the day of the shooting, Minnesota Governor Jesse Ventura added that Columbine "supports conceal-and-carry because of the fact that what happens when a group of unarmed individuals are confronted with people with weapons like this, you have no defense" (in Verhovek, 1999). While pro-gun advocates were virtually silent following Virginia Tech, as the main discourse, even when guns were involved, focused on mental health, the debate was immediately recharged after Sandy Hook. Wayne LaPierre, current president of the NRA, responded to the shooting by saying, "The only thing that stops a bad guy with a gun is a good guy with a gun" (in Bilton, 2013). He then suggested that every school should have armed guards by the time classes resumed in the spring (Bilton, 2013).

Conversely, those in opposition have claimed that it is the ease and availability of guns that led to the shootings in the first place. Some even suggest that besides being unrealistic in terms of manpower and financial resources, placing armed security guards or law enforcement at every single school nationwide would do nothing to prevent such attacks:

There were two armed law enforcement officers at that campus [Columbine], and you see what happened - 15 dead. (Senator Diane Feinstein, in Bilton, 2013)

People like Mr. LaPierre want us to believe that civilians can be trained to use lethal force with cold precision in moments of fear and crisis. That requires a willful ignorance about the facts. Police officers know that firing a weapon is a huge risk; that's why they avoid doing it. In August [2012], New York City police officers opened fire on a gunman outside the Empire State Building. They killed him and wounded nine bystanders. (Rosenthal, 2012)

The volatility in the back-and-forth argument between gun control and gun rights activists continued to grow as the state of New York passed one of the strictest gun control packages within a month of the Sandy Hook shooting, and President Obama convened a panel on mass violence, led by Senator Joe Lieberman. With the support of the usual champions - California Senator Diane Feinstein, New York Congresswoman Carolyn McCarthy, and New Jersey Senator Frank Lautenberg - a number of gun control measures were introduced. Still, given the partisan divide of Congress, it is unlikely that many of these measures will be enacted into law, as witnessed with Columbine (Schildkraut \& Hernandez, 2013; Soraghan, 2000).

\section{| A Rhetorical Ouroboros?}

In the movie National Lampoons: Van Wilder (Abrams, Levy, \& Becker, 2002), the main character opined "Worrying is like a rocking chair. It gives you something to do, but it doesn't get you anywhere." While this may seem to be an outrageous proposition in the context of school shootings, it does put the discourse in a perspective of sorts. In the aftermath of school shootings such as Columbine, Virginia Tech, and Sandy Hook, legislative bill after legislative bill are rushed to the floor, yet few (if any) pass. Following Columbine, over 800 bills aimed at regulating gun ownership and gun shows were introduced, yet only about $10 \%$ of these bills were enacted into law (Soraghan, 2000). It didn't bode well for legislators that the very issue they were trying to address had been figured out by high school youth (Schildkraut, 2012b). In a 1998 class paper, Eric Harris identified the gaps in the Brady bill for the control of gun sales that eventually enabled him (or more precisely, his friend) to purchase guns: "the biggest gaping hole is that background checks are only required for licensed dealers ... not private dealers ... private dealers can sell shotguns and rifles to anyone who is 18 or older" (Jefferson County Sheriff's Office, 1999, p. 26,538).

After Virginia Tech, and following the passage of the NICS Improvement Amendments Act, the majority of the funds made available were never claimed and millions of records still have not been added to background check systems, leaving many people who should be disqualified eligible to legally purchase firearms (Brady Campaign Press Release, 2011; Witkin, 2012). These lapses in reporting also enabled other mass shooters, including Jared Loughner (who recently pled guilty to the Tucson, Arizona shooting of Congresswoman Gabrielle Giffords and others, despite spending a year and a half being "incompetent to stand trial") and James Holmes (who shot 70 people at a midnight showing of The Dark Knight Rises and, nine months after the shooting, has decided to claim the insanity defense) to purchase their guns legally. These reporting systems, however, are predicated on the fact that a person has seen a 
professional, either as an in-patient or out-patient, to be declared to have a mental illness; it fails to account for the millions of people who go undiagnosed each year (Schildkraut \& Hernandez, 2013). It also stigmatizes those with mental illnesses who do not try to purchase weapons but instead try to lead normal lives. As David Shern, the chief executive of Mental Health America, noted, “This is a classic example of a well-intentioned effort that's going to have almost no effect and, in fact, is going to do harm" (in Luo, 2007).

There are two glaring issues with this continued reaction. The first is that, as Howard Kurtz (2012) astutely notes, "the news business, with few exceptions, pays little attention to the gun issue except in the immediate aftermath of the latest mass shooting in Columbine, Virginia Tech, Tucson, Aurora, or Newtown." As quickly as the media latches onto the issue, something else captures its attention and they move on. The second is the adequate addressing of existing laws. Though he received a tremendous amount of criticism, NRA president Wayne LaPierre raised this issue (Lichtblau \& Rich, 2012). Why should politicians continue to crank out new legislation instead of enforcing the existing bills in place from the previous tragedy that failed to prevent the current event? This is the cyclical challenge that likely will not be solved.

Still, the disproportionally high fear of school shootings leads many - parents, students, faculty, politicians, and the media - to worry about when the next event will occur and who will be the target. Following Columbine, schools across the nation saw a surge in metal detectors and identification badges. These are "feel better" responses, but do not actually guarantee that a gun will not get into the school (see Addington, 2014). At airports across the nation, people have been able to get firearms as large as .40 caliber through TSA security screening checkpoints, despite heighten procedures following the September 11th terrorist attacks (see, for example, Quinn, 2010).

What escapes all of the chatter about school shootings is how unlikely it is that a person will be the victim of a school shooting. Between the 1992-1993 and 1997-1998 school years (pre-Columbine), over 50 million children attended schools across the nation (Sanchez, 1998). During that same time period, 226 kids were killed in schoolshooting related deaths (Bernard, 1999; Donohue, Schiraldi, \& Ziedenberg, 1998). This means that the probability of any student becoming the victim of a school shooting during these years was at less than one in five-ten thousandths (e.g., < 0.0005). These same children had a greater chance of being struck by lightning (Donohue et al., 1998; Sanchez, 1998). But, as Lloyd Christmas (Jim Carrey) pondered in Dumb and Dumber, "So you're telling me there's a chance?" (in Krevoy et al., 1994). Regardless, it doesn't stop people from worrying that they or their children will be the next victim and trying to reduce the possible risk that is assumed. The problem is that once you reduce the odds to a million and one, the next obstacle is reducing them to one in ten-million. Despite the fact that one can never have a risk of zero, it doesn't keep people from worrying, though it gets them nowhere.

\section{So What Is The Answer?}

It is clear that we will never truly know "why" these events have happened. The people who can answer such a question are not here. Sure, Cho left a detailed manifesto in which he rambled on about his disdain for wealthy kids and hedonism (Schildkraut, 2012b). For Columbine, there potentially is a similarly documented response straight from the killers. These tapes, infamously dubbed "The Basement Tapes," have been sealed from the public and won't be released until 2026 (at the earliest) out of fear of copycat attacks (Schildkraut, 2012b). So until we can hear it straight from the killers' mouths, we are left to speculate as to their motive. Sandy Hook, however, presents an even greater challenge, as Adam Lanza doesn't appear to have left the same video diary as his predecessors. This gap appears to only fuel the fire of speculation, rather than allowing society to focus elsewhere.

Given the reliance of the public discourse on media reporting of such tragedies, we are perhaps left with more questions than answers regarding the potential causes (and therefore implied remedies) for such cases. Clearly, the three ring circus of violent media, guns, and mental illness are insufficient, even in combination, to explain the complexity of school massacres. The following quote from an editorial by Maureen Dowd illustrates the ridiculous simplicity of characterizing an event such as Columbine as solely related to gun availability and policies (regardless of whether the argument is that there are too many or too few restrictions on firearms):

As Jesse Ventura said, if only the concealed weapons law had passed in Colorado, students and teachers secretly packing heat could have cut down those two outcasts. The problem is not that bad guys have guns; it's that good guys don't. (Dowd, 1999)

Similarly, in combination violent and fantasy media, guns, and uncontrolled rage cannot be fingered as the cause, 
as illustrated in another quote from Dowd's op-ed:

Just blame Marilyn Manson, Oliver Stone, the Internet, video games, Magic cards, Goths. Here's a good sound bite: Software makes people go nuts, not hardware. Guns don't kill people; trench coats kill people. Guns don't kill people; people who have not reached closure with their anger kill people. (Dowd, 1999)

It is not our position simply to the finger at the news media and/or politicians, and it is obviously pointless to expect the media industry and political apparatus to disregard the relevance of shocking school massacres. As selfreflective media personnel commented after the Columbine incident, it's impossible for media not to cover such cases.

[T] he Sheriff speaks directly with a female reporter at KUSA [unnamed in transcripts] and he suggests that the media coverage sparks the possibility of copycat attacks. "Well, you just wonder how much - when the attention like this media attention gets on it, that this is broadcast all over the United States and other people get the same idea..." The reporter responds, "And the conflict is that you can't not cover it. But then again, you know, the dilemma is that 15 seconds of fame of whatever the motive is." Stone concludes, "Yes, I understand" (Savidge et al. 1999).

Similarly, the public expects its leaders to comment on such cases, and therefore public leaders walk a similar line in their responsibility to step up as leaders and spokespersons for their constituencies, and perhaps also to advance their political agendas. After all, public figures will frequently attempt to connect their agendas rhetorically to the events, an action which capitalizes on the affective intensity of riveted audience. As John Velleco commented. "Unfortunately, there are going to be politicians who are going to climb over the bodies of the victims and pursue an agenda" (in Brooke, 1999). Clearly the news media and politicians are both necessary to the functioning of civil society; however, such cases also make both their necessity and limited nature clear.

Even for academicians, the complex causes of school massacres are extremely difficult to pin-point, for various reasons. First, there are relatively few cases of school massacres, and therefore it is impossible to identify a set of nomothetic causes from the examination of a small number of cases. Second, in the case studies that have been conducted, the causes seem to vary from case to case. Therefore, no set of causes has been identified as sufficient to produce a school massacre.7 It is true that the "big three" of violent media, guns, and mental illness often figure into the situation; however, these are insufficient to explain school massacres in themselves. Case in point is the fact that millions of persons may consume violent media, own firearms, and have mental illnesses, often at the same time, yet school massacres are rather rare.

How, then, to clarify the causes of these troubling events? We argue that what is needed is a protracted, extended discourse about school shootings and related massacres, one which explores their cultural meaning and causes. Given the new media's relatively short issue-attention cycle for any specific issue, this apparently cannot take place in the news media. In addition, given the wide array of spheres on which politicians must comment, it is unrealistic to expect such public figures to spend a long time on violence, as it will always be superseded in short order, and public attention and/or media attention shift elsewhere.

However, such a slow and protracted exploration of relevant issues is taking place in various scholarly disciplines in the social sciences, education, and humanities (see Muschert, 2007a \& 2010 for a review). But if such exploration is going on in the academic realms, why does it not then bleed over into the popular, mass market discourse of news media and politicians? The divide persists more sharply in the U.S. between the so-called ivory tower and more popular modes of public discourse. In part, the academic discourse in the U.S. is frequently divorced from the public and political discourse, and academics are rarely professionally rewarded for informing news media and politicians. In short, these parties simply do not converse with one another very frequently, and therefore there is little opportunity for academics to inform journalists and politicians as to their findings and thinking about issues, just as there little chance for the opposite conversation to take place. What is needed in the case of school massacres is a discussion among these parties regarding the complex individual, community-level, and socio-cultural causes of school massacres (and violence more generally) (see Henry, 2000 \& 2009; Muschert 2007a \& 2010; Muschert et al., 2014).

Nonetheless, there may be glimmers of hope. Over the last decades, many academic disciplines have taken strides to make their expertise more public, and politicians and policy makers are increasingly insisting on evidence-based policies and/or independent evaluation of policy outcomes. It is our hope that this trend toward sharing information and cross-fertilizing academic, media, and political discourses will continue, especially in the case of mass violence in various locations, including schools. Such an extended and protracted discussion is necessary, because without 
intelligent and informed analysis of social problems, such as school violence, policies may be ineffective (or even counter-productive) in preventing and mitigating the issue, without which we are in danger of continuing to live in disproportionate fear of such tragedies.

\section{Endnotes}

1. In this event, 20-year-old Adam Lanza forcefully entered Sandy Hook Elementary School in Newtown, Connecticut and opened fire. The shooting left 20 first grade students and six educators, including the school's principal, dead. Lanza also had shot and killed his mother Nancy prior to the rampage.

2. On April 20, 1999, Columbine seniors Eric Harris (18) and Dylan Klebold (17) opened fire on their school. They shot and killed 12 students and one teacher before committing suicide in the school's library.

3. On April 16, 2007, Virginia Tech senior Seung-Hui Cho (23) shot and killed two students in the West Ambler Johnston dormitory on campus. After a two-hour break, during which he mailed his now infamous multimedia manifesto to NBC, Cho opened fire in Norris Hall, killing an additional 30 students and faculty. He killed himself as police gained entry to the building.

4. For a discussion of the complexities of assigning culpability to youthful offenders, see Cerulo (1998), Muschert \& Janssen (2012), Spencer (2005), and Spencer \& Muschert (2009).
5. In Warner \& Curtiz (1942).

6. An Ouroboros is an ancient symbol that represents cyclicality. In its current form, it is the idea that there is no beginning or end to a discussion following school shootings, and that this discussion does not lead to any progress toward a solution.

7.Muschert (2007a) points out that individual access to guns are the only necessary cause, for school shootings to occur. However, similar attacks have taken place without guns, and have involved bombs (as in the 1927 Bath, Michigan school massacre) or knives (as occurred in various places in China in 2012, on the same day as the Sandy Hook massacre).

\section{References}

Abrams, P., \& Levy, R.L. (Producers), \& Becker, W. (Director). (2002). National Lampoon's Van Wilder [Motion picture]. United States: Lions Gate Films.

Addington, L.A. (2014). Surveillance and security approaches across public school levels. In G.W. Muschert, S. Henry, N.L. Bracy, \& A.A. Peguero (Eds.), Responding to school violence: Confronting the Columbine effect. Boulder, CO: Lynne Rienner.

Agger, B. (2007). Cho, not Che? Positioning Blacksburg in the political. Fast Capitalism, 3(1). Retrieved April 27, 2013 from http://www.uta.edu/huma/agger/fastcapitalism/3_1/agger. html.

Bernard, T. (1999). Juvenile crime and the transformation of juvenile justice: Is there a juvenile crime wave? Justice Quarterly, 16(2), 337-356.
Blabbermouth.net. (2010, November 10). Marilyn Manson signs with Cooking Vinyl Records. Retrieved April 27, 2013 from http://www.blabbermouth.net/news. aspx ?mode $=$ Article\&newsitemID $=149002$.

Bonnie, R.J., Reinhard, J.S., Hamilton, P., and McGarvey, E.L. (2009). Mental health system transformation after the Virginia Tech tragedy. Health Affairs, 28(3), 793-804.

BoxOffice.com. (n.d.). Natural Born Killers - BoxOffice.com. Retrieved April 27, 2013 from http://www.boxoffice.com/ statistics/movies/natural-born-killers-1994.

Brady Campaign Press Release. (2011, January 7). One million mental health records now in Brady background check system. BradyCampaign.org. Retrieved from http://bradycampaign. org/media/press/view/1336/. 
Burns, R., \& Crawford, C. (1999). School shootings, the media, and public fear: Ingredients for a moral panic. Crime, Law \& Social Change, 32, 147-168.

Cerulo, K.A. (1998). Deciphering violence: The cognitive structure of right and wrong. New York: Routledge.

Chyi, H., \& McCombs, M. (2004). Media salience and the process of framing: Coverage of the Columbine school shootings. Journalism and Mass Communication Quarterly, 81(1), 22-35.

Donohue, E., Schiraldi, V., \& Ziedenberg, J. (1998, July). School house hype: School shootings and the real risks kids face in America. Washington, D.C.: Justice Policy Institute. Retrieved from http://www.justicepolicy.org/uploads/justicepolicy/ documents/98-07_rep_schoolhousehype_ji.pdf.

Doom. (n.d.). In Wikipedia. Retrieved April 27, 2013 from https://en.wikipedia.org/wiki/Doom_\%28video_game\%29.

Elsass, H.J., \& Schildkraut, J. (2013). He said, she said: Gender and media influences on school shootings panic. Manuscript submitted for publication (copy on file with author).

Graber, D.A. (1980). Crime news and the public. Chicago, IL: University of Chicago Press.

Henry, S. (2000). What is school violence? An integrated definition. Annals of the American Academy of Political and Social Science, 567, 16-29.

Henry, S. (2009). School violence beyond Columbine: A complex problem in need of an interdisciplinary analysis. American Behavioral Scientist, 52(9), 1246-1265.

Jefferson County Sheriff's Office. (1999). Columbine documents. Golden, CO: Jefferson County Sheriff's Office Records Unit. Retrieved from http://www.schoolshooters.info/PL/Original_ Documents_files/JCSO\%2025,923\%20-\%2026,859.pdf.

Jewkes, Y.E. (2004). Media \& crime: Key approaches to criminology. Los Angeles, CA: Sage Publications.

Kellner, D. (2003). Media spectacle. London: Routledge.

Kellner, D. (2008a). Guys and guns amok: Domestic terrorism and school shootings from the Oklahoma City bombing to the Virginia Tech massacre. Boulder, CO: Paradigm Publishers.

Kellner, D. (2008b). Media spectacle and the "Massacre at Virginia Tech". In B. Agger \& T.W. Luke (Eds.), There is a gunman on campus (pp. 29-54). Lanham, MD: Rowan \& Littlefield Publishers, Inc.

Krevoy, B., Stabler, S., Wessler, C.B., Farrelly, B., Olson, G. (Producers), \& Farrelly, P \& Farrelly, B. (Directors). (1994). Dumb and Dumber [Motion picture]. United States: New Line Cinema.

Larkin, R.W. (2007). Comprehending Columbine. Philadelphia, PA: Temple University Press.

Maguire, B., Weatherby, G.A., \& Mathers, R.A. (2002). Network news coverage of school shootings. The Social Science Journal, 39(3), 465-470.
Mayr, A., \& Machin, D. (2012). The language of crime and deviance: An introduction to critical linguistic analysis in media and popular culture. London: Continuum International Publishing Group.

Muschert, G.W. (2007a). Research in school shootings. Sociology Compass, 1(1), 60-80.

Muschert, G.W. (2007b). The Columbine victims and the myth of the juvenile superpredator. Youth Violence and Juvenile Justice, 5(4), 351-366.

Muschert, G.W. (2010). School shootings. Pp. 73-89 in Martine Herzog-Evans (ed.) Transnational Criminology Manual, Volume 2. Nijmegen, Netherlands: Wolf Legal Publishing.

Muschert, G.W., \& Carr, D. (2006). Media salience and frame changing across events: Coverage of nine school shootings, 1997-2001. Journalism and Mass Communication Quarterly, 83(4), 747-766.

Muschert, G.W., Henry, S., Bracy, N.L., \& Peguero, A.A. (eds.). (2014). Responding to school violence: Confronting the Columbine effect. Boulder, CO: Lynne Rienner.

Muschert, G.W. \& Janssen, L. (2012). Deciphering rampage: Assigning blame to youth offenders in news coverage of school shootings. In G.W. Muschert \& J. Sumiala (Eds.), School shootings: Mediatized violence in a global age (pp. 181-200). Bingley, UK: Emerald Publishing.

Muschert, G.W. \& Ragnedda, M. (2010). Media and violence control: The framing of school shootings. In W. Heitmeyer, H. G. Haupt, S. Malthaner, \& A. Kirschner (Eds.), The Control of Violence in Modern Society: Multidisciplinary Perspectives, From School Shootings to Ethnic Violence (pp. 345-361). New York: Springer Publishing.

Newman, K.S. (2006). School shootings are a serious problem. In S. Hunnicutt (Ed.), School Shootings (pp. 10-17). Farmington Hills, MI: Greenhaven Press.

NRA.com. (n.d.). NRA history: About us. Retrieved from http://home.nra.org/history/document/about.

Pew Research Center for the People and the Press. (2012, December 20). Election, tragedies dominate top stories of 2012. Retrieved from http://www.people-press.org/2012/12/20/ election-tragedies-dominate-top-stories-of-2012/.

Pew Research Center for the People and the Press. (2007, April 25). Widespread interest in Virginia Tech shootings, but public paid closer attention to Columbine. Retrieved from http://people-press.org/report/322/ widespread-interest-in-virginia-tech-shootings/.

Pew Research Center for the People and the Press. (1999, December 28). Columbine shooting biggest news draw of 1999. Retrieved from http://people-press.org/report/48/ columbine-shooting-biggest-news-draw-of-1999.

Pew Research Center's Project for Excellence in Journalism. (2006, March 13). Cable TV audience: 2006 annual report, Fox News vs. CNN. Retrieved from http://www.journalism. org/node/507. 
Robinson, M.B. (2011). Media coverage of crime and criminal justice. Durham, NC: Carolina Academic Press.

Rudin, S., Lawrence, L., Caplan, T., Schroeder, A., \& Berg, B.M. (Producers), \& Heckerling, A. (Director). (1995). Clueless [Motion picture]. United States: Paramount Pictures.

Schildkraut, J. (2012a). Media and massacre: A comparative analysis of the reporting of the 2007 Virginia Tech shootings. Fast Capitalism, 9(1). Retrieved from http://www.uta.edu/ huma/agger/fastcapitalism/9_1/schildkraut9_1.html.

Schildkraut, J. (2012b). The remote is controlled by the monster: Issues of mediatized violence and school shootings. In G.W. Muschert \& J. Sumiala (Eds.), School Shootings: Mediatized Violence in a Global Age (pp. 235-258). Bingley, United Kingdom: Emerald Publishing Group Limited.

Schildkraut, J., \& Hernandez, T.C. (2013). Laws that bit the bullet: A review of legislative responses to school shootings. Manuscript submitted for publication (copy on file with author).

Schildkraut, J., \& Muschert, G.M. (2013). Media salience and the framing of mass murder in schools: A comparison of the Columbine and Sandy Hook massacres. Manuscript submitted for publication (copy on file with author).

Schildkraut, J., Elsass, H.J., \& Stafford, M.C. (2013). Could it happen here? Moral panics, school shootings, and fear of crime among college students. Manuscript submitted for publication (copy on file with author).

Spencer, J.W. (2005). It's not as simple as it seems: Ambiguous culpability and ambivalent affect in media representations of violent youth. Symbolic Interaction, 28(1), 47-65.
Spencer, J.W. \& Muschert, G.W. (2009). The contested meaning of the crosses at Columbine. American Behavioral Scientist, 52(10), 1371-1386.

Springhall, J. (1999). Violent media, guns, and moral panics: The Columbine High School Massacre, 20 April 1999. Paedagogica Historica, 35(3), 621-641.

Soraghan, M. (2000). Colorado after Columbine: The gun debate. State Legislatures, 26(6), 14-21.

TheWebStats.com. (2011). MSNBC.com. Retrieved from http:// www.thewebstats.com/msnbc.com.

Virginia Tech Review Panel. (2007). Mass Shootings at Virginia Tech April 16, 2007: Report of the Review Panel. Arlington: Governor's Office of the Commonwealth of Virginia. Retrieved from http://www.governor.virginia.gov/ TempContent/techpanelreport.cfm.

Walker, W. (Producer). (1999, May 6). Larry King Live [Television Broadcast]. Atlanta, GA: Cable News Network and Turner Broadcasting System, Inc. Transcript retrieved from http://www.cnn.com/ALLPOLITICS/stories/1999/05/07/ gore.lkl.transcript/.

Warner, J.L. (Producer), \& Curtiz, M. (Director). (1942). Casablanca [Motion picture]. United States: Warner Bros.

Ziskin, L., \& Bryce, I. (Producers), \& Raimi, S. (Director). (2002). Spiderman [Motion picture]. United States: Columbia Pictures.

\section{News Article Cited}

Associated Press. (2013, May 1). Newtown victim's daughter confronts Sen. Ayotte over gun control bill vote. Fox News. Retrieved from http://www.foxnews.com/ politics/2013/05/01/newtown-victim-daughter-confronts-senayotte-over-gun-control-bill-vote/.

Bilton, N. (2013, January 7). Smart guns can't kill in the wrong hands. The New York Times. Retreived from http://bits.blogs. nytimes.com/2013/01/06/disruptions-smart-gun-technologycould-prevent-massacres-like-newtown/.

Broder, J.M. (1999, May 10). Washington memo; Searching for answers after school violence. The New York Times. Retrieved from http://www.nytimes.com/1999/05/10/us/ washington-memo-searching-for-answers-after-school-violence. html ?pagewanted $=$ all \&src $=$ pm.
Brooke, J. (1999, April 23). Terror in Littleton: The gun debate; Shootings firm up gun control cause, at least for present. The New York Times. Retrieved from http://www.nytimes. com/1999/04/23/us/terror-littleton-gun-debate-shootingsfirm-up-gun-control-cause-least-for.html.

Brooks, D. (2007, April 19). The mortality line. The New York Times. Retrieved from http://select.nytimes. com/2007/04/19/opinion/19brooks.html?hp.

Bruni, F. (1999, May 13). Senate narrowly rejects plan to restrict gun-show sales. The New York Times. Retrieved from http:// www.nytimes.com/1999/05/13/us/senate-narrowly-rejectsplan-to-restrict-gun-show-sales.html.

Carr, D. (2013, January 13). Guns, maps and data that disturb. The New York Times. Retrieved from http://www.nytimes. com/2013/01/14/business/media/guns-maps-anddisturbing-data.html?_r $=0$. 
Douthat, R. (2013, April 13). Media balance and bias. The New York Times. Retrieved from http://www.nytimes. com/2013/04/14/opinion/sunday/douthat-media-balanceand-bias.html.

Dowd, M. (1999, April 25). Liberties; Hunker in the bunker. The New York Times. Retrieved from http://www.nytimes. com/1999/04/25/opinion/liberties-hunker-in-the-bunker. html.

Dwyer, J., \& Rueb, E.S. (2012, December 16). In a town of traditions, grief engulfs holiday joy. The New York Times. Retrieved from http://www.nytimes.com/2012/12/16/ nyregion/for-newtown-horror-halts-a-season-of-celebration. html.

Garofoli, J. (2007, April 20). New-media culture challenges limits of journalism ethics. Retrieved from http://articles.sfgate. com/2007-04-20/news/17242016_1_new-media-traditionalmedia-traditional-news-sources/3.

Glaberson, W. (2012, December 14). Nation's pain is renewed, and difficult questions are asked once more. The New York Times. Retrieved from http://www.nytimes.com/2012/12/15/ nyregion/sandy-hook-shooting-forces-re-examination-oftough-questions.html?_r=0.

Hamilton, W.L. (1999, May 6). How suburban design is failing teen-agers. The New York Times. Retrieved from http://www. nytimes.com/1999/05/06/garden/how-suburban-design-isfailing-teen-agers.html?pagewanted $=$ all\&src $=$ pm.

Harmon, A. (2012, December 18). Fearing a stigma for people with autism. The New York Times. Retrieved from http://www. nytimes.com/2012/12/18/health/fearing-a-stigma-for-peoplewith-autism.html.

Hendrix, G. (2007, April 20). Violent disagreement: What Seung-Hui Cho got wrong about Oldboy. Retrieved April 20, 2013 from http://www.slate.com/id/2164753/.

Herbert, B. (1999, April 22). In America; Addicted to violence. The New York Times. Retrieved from http://www.nytimes. com/1999/04/22/opinion/in-america-addicted-to-violence. html.

Kain, E. (2012, November 24). 'Black Ops 2' tops 11M units sold in first week, no sign of Call of Duty fatigue yet. Forbes. Retrieved April 27, 2013 from http://www.forbes.com/sites/ erikkain/2012/11/24/black-ops-2-tops-11m-units-sold-in-firstweek-no-signs-of-call-of-duty-fatigue-yet/.

Kurtz, H. (2012, December 17). In between mass shootings, the media have been MIA on guns. The Daily Beast. Retrieved from http://www.thedailybeast.com/articles/2012/12/17/ in-between-mass-shootings-the-media-has-been-mia-on-guns. html.

Lewin, T. (1999, May 2). Terror in Littleton: The teenage culture; Arizona high school provides glimpse inside cliques' divisive webs. The New York Times. Retrieved from http:// www.nytimes.com/1999/05/02/us/terror-littleton-teenage-culture-arizona-high-school-provides-glimpse-inside. $\mathrm{html}$ ?pagewanted $=$ all \&src $=\mathrm{pm}$.
Lichtblau, E. (2013, January 12). Makers of violent video games marshal support to fend off regulation. The New York Times. Retrieved April 27, 2013 from http://www.nytimes. com/2013/01/12/us/politics/makers-of-violent-video-gamesmarshal-support-to-fend-off-regulation.html?_r $=0$.

Lichtblau, E., \& Rich, M. (2012, December 22). N.R.A. envisions 'a good guy with a gun' in every school. The New York Times. Retrieved from http://www.nytimes.com/2012/12/22/us/ nra-calls-for-armed-guards-at-schools.html.

Luo, M. (2007, May 2). Privacy laws slow effort to widen gun-buyer data. The New York Times. Retrieved from http://query.nytimes.com/gst/fullpage. html?res=9803E1DE103EF931A35756C0A9619C8B63.

Manson, M. (1999, June 24). Columbine: Whose fault is it? Rolling Stone. Retrieved from http://www.rollingstone.com/ culture/news/columbine-whose-fault-is-it-19990624.

Moss, M., \& Rivera, R. (2012, December 16). In town at ease with its firearms, tightening gun rules was resisted. The New York Times. Retrieved from http://www.nytimes. com/2012/12/17/nyregion/in-newtown-conn-a-stiffresistance-to-gun-restrictions.html? pagewanted=all\&_r $=0$.

Quinn, K. (2010, December 17). Man boards plane at IAH with loaded gun in carry-on. ABC 13 News. Retrieved from http://abclocal.go.com/ktrk/story?section=news/ local\&id $=7848683$.

Roberts, J. (2009, February 11). Gun used in rampage traced to Va. Shops. CBS News. Retrieved from http://www.cbsnews. com/2100-500690_162-2695059.html.

Rosenthal, A. (2012, December 21). The N.R.A. crawls from its hidey hole. The New York Times. Retrieved from http://www. nytimes.com/2012/12/22/opinion/the-nra-crawls-from-itshidey-hole.html.

Sanchez, R. (1998, May 23). Educators pursue solutions to violence crisis; as deadly sprees increase, schools struggle for ways to deal with student anger. The Washington Post. Retrieved from http://pqasb.pqarchiver.com/ washingtonpost/.

Savidge, M., Kagan, D., Lin, C., Chen, J., Clark, T., Shaw, B., Blitzer, W., \& Thomas, P. (1999, April 20). Gunmen rampage through Colorado high school. CNN Breaking News. Atlanta, GA: CNN television broadcast.

Seelye, K.Q. (1999, May 20). Campaigns find all talk turns to Littleton. The New York Times. Retrieved from http://www. nytimes.com/1999/05/20/us/campaigns-find-all-talk-turnsto-littleton.html.

Seelye, K.Q., \& Brooke, D. (1999, May 2). Terror in Littleton: The gun lobby; Protest greets N.R.A. meeting in Denver. The New York Times. Retrieved April 26, 2013 from http://www. nytimes.com/1999/05/02/us/terror-in-littleton-the-gunlobby-protest-greets-nra-meeting-in-denver.html. 
Stolberg, S.G. (1999, May 9). The nation: By the numbers; Science looks at Littleton, and shrugs. The New York Times. Retrieved from http://www.nytimes.com/1999/05/09/weekinreview/ the-nation-by-the-numbers-science-looks-at-littleton-andshrugs.html.

Verhovek, S.H. (1999, April 22). Terror in Littleton: The overview; 15 bodies are removed from school in Colorado. The New York Times. Retrieved from http://www.nytimes.com/1999/04/22/ us/terror-in-littleton-the-overview-15-bodies-are-removedfrom-school-in-colorado.html? pagewanted $=$ all $\& \mathrm{src}=\mathrm{pm}$.

Witkin, G. (2012, April 16). On anniversary of Virginia Tech shooting, law to close loophole hasn't accomplished much. iWatchNews.org. Retrieved from http://www.iwatchnews. org/2012/04/16/8660/anniversary-virginia-tech-shooting-lawclose-loophole-hasnt-accomplished-much. 
